\title{
Pengembangan Bahan Ajar Problem Based Learning untuk Pembelajaran Daring dengan Platform Edmodo
}

\author{
Ana Fitri Aeni ${ }^{1}$, Anwar Mutaqin ${ }^{2}$, Yani Setiani ${ }^{3}$ \\ 1,2,3 Program Studi Pendidikan Matematika, Universitas Sultan Ageng Tirtayasa, \\ Jl. Raya Jakarta Km. 04 Pakupatan Kota Serang \\ Anafitriaeni@gmail.com
}

\begin{abstract}
The globa Covid-19 pandemic has stopped all activities that invite the public. One of them is teaching and learning activities in schools. To deal with this incident, the government announcement to conduct online learning called PJJ (Pembelajaran Jarak Jauh). The use of LMS (Learning Management System) is very helpful for teachers to teach online. During the pandemic, teachers use Whatsapp and books to teach.The LMS used in this study is Edmodo. The purpose of this study is to determine the validity of using PBL teaching materials for online learning with the Edmodo platform and to find out how students respond when using teaching materials for online learning. The research design used is Research and Development (R\&D). The subjects of this study were 10 students of SMP BCK Cilegon. The results of this study are: (1) the teaching materials as result of this development were declared quite valid by material experts with a percentage of $81.25 \%$ and media experts with a percentage of $79.17 \%$, and (2) the use of teaching materials received a positive response from students.
\end{abstract}

Keywords: Teaching Materials, Problem Based Learning, Edmodo

\begin{abstract}
Abstrak
Pandemi Covid-19 atau yang dikenal sebagai virus korona secara global, membuat semua aktivitas yang mengundang khalayak ramai dihentikan. Salah satunya adalah kegiatan belajar-mengajar yang dilakukan di sekolah. Untuk mensiasati kejadian tersebut, pemerintah mengeluarkan pengumuman untuk melakukan pembelajaran secara online atau daring yang disebut dengan PJJ (Pembelajaran Jarak Jauh). Penggunaan LMS (Learning Management System) sangat membantu guru untuk mengajar secara daring atau online. Selama pandemi, guru mengajar melalui aplikasi Whatsapp dan menggunakan buku sebagai bahan ajar. LMS yang dipilih dalam penelitian ini adalah Edmodo. Tujuan dari penelitian ini yaitu untuk mengetahui kevalidan dari penggunaan bahan ajar PBL untuk pembelajaran daring dengan platform Edmodo dan mengetahui bagaimana respon siswa saat menggunakan bahan ajar untuk pembelajaran daring. Desain penelitian yang digunakan yaitu penelitian dan pengembangan atau Research and Development (R\&D). Subjek penelitian ini adalah 10 siswa SMP BCK Cilegon. Hasil dari penelitian ini yaitu: (1) bahan ajar hasil pengembangan ini dinyatakan cukup valid oleh ahli materi dengan persentase $81,25 \%$ dan ahli media dengan persentase $79,17 \%$, dan (2) penggunaan bahan ajar mendapat respon yang positif dari siswa.
\end{abstract}

Kata kunci: Bahan Ajar, Problem Based Learning, Edmodo

Copyright (c) 2021 Ana Fitri Aeni, Anwar Mutaqin, Yani Setiani

$\triangle$ Corresponding author: Khairisti Iis handayani

Email Address: Anafitriaeni@gmail.com (Jl. Raya Jakarta Km. 04 Pakupatan Kota Serang)

Received 15 Juni 2021, Accepted 22 Juni 2021, Published 23 Juni 2021

\section{PENDAHULUAN}

Permendikbud Nomor 65 Tahun 2013 tentang standar proses menjelaskan bahwa model pembelajaran yang sesuai dengan Kurikulum 2013 adalah: (1) pembelajaran inkuiri, (2) pembelajaran discovery, (3) pembelajaran berbasis projek, (4) pembelajaran berbasis masalah. Namun, dalam perkembangannya masih ada saja guru yang belum menerapkan secara maksimal K-13. Dalam proses pembelajaran yang terjadi, diperlukan sarana penunjang yang baik agar proses pembelajaran tersebut berjalan dengan baik. Salah satu sarana penunjang yang dibutuhkan adalah bahan ajar (Agustina \& Vahlia, 2016). Menurut Depdiknas (2008) bahan ajar adalah bagian penting dalam pelaksanaan pembelajaran di sekolah. Melalui bahan ajar, guru akan lebih mudah dalam melaksanakan pembelajaran dan siswa akan 
lebih terbantu dan mudah dalam belajar. Untuk itu, pemilihan dan penggunaan bahan ajar yang baik dapat membuat siswa lebih paham dalam belajar matematika.

Salah satu model pembelajaran yang mengaitkan permasalahan matematika dengan kehidupan sehari-hari adalah model pembelajaran Problem Based Learning (PBL) atau dikenal juga sebagai model pembelajaran berbasis masalah. Pembelajaran berbasis masalah dirancang untuk membantu siswa mengembangkan kemampuan berpikir dan mengembangkan kemampuan memecahkan masalah, belajar berbagai peran orang dewasa melalui keterlibatan mereka dalam pengalaman-pengalaman nyata (Khotimah et al., 2012). Mengaitkan permasalahan yang berkaitan dengan kehidupan sehari-hari dilakukan secara bertahap kepada siswa, agar siswa mampu terlebih dahulu memahami konsep matematika yang diajarkan.Salah satu materi matematika yang cocok diterapkan dalam model pembelajaran berbasis masalah adalah materi Persamaan Linier Satu Variabel (PLSV). Dalam materi PLSV ini, banyak sekali hal yang berkaitan dengan kehidupan sehari-hari. Misalnya, menentukan harga sebuah telur jika harga $1 / 4 \mathrm{~kg}$ telur adalah Rp. 10000,00.

Bahan ajar PBL dipilih karena cocok untuk diterapkan dalam pembelajaran matematika. PBL (Problem Based Learning) terkait dengan belajar penemuan (discovery learning) dan kemampuan matematis. Pada pembelajaran matematika, penilaian terhadap aspek kognitif, afektif dan psikomotorik saling berhubungan satu sama lain. Aspek afektif siswa berhubungan dengan sikap dan emosional siswa terhadap matematika. Pada aspek kognitif, siswa dituntut untuk belajar menemukan informasi penting atau solusi yang dapat membantu dalam menyelesaikan sebuah masalah. Sedangkan pada aspek psikomotorik, siswa dituntut untuk memiliki kemampuan matematis yang baik dalam menyelesaikan masalah. Guru juga dapat membimbing siswa untuk melakukan investigasi dari sebuah permasalahan tersebut. Pada dasarnya ketiga aspek tersebut tidak bisa dipisahkan satu sama lain, karena ketiga aspek tersebut saling terkait. Apabila ketiga aspek ini dikembangkan dalam diri siswa, maka siswa akan merasa lebih mudah dalam menerapkan fakta, konsep dan operasi matematika (Surmiyati et al., 2014).

Perkembangan jaman yang semakin maju membuat perkembangan teknologi juga semakin maju. Perkembangan teknologi menawarkan banyak kemudahan bagi manusia salah satunya adalah memperoleh informasi secara cepat. Salah satu perkembangan teknologi yang sudah tidak asing lagi adalah smartphone dan internet. Berdasarkan survei yang dilakukan oleh KOMINFO pada tahun 2017 adalah sebanyak 66,3\% masyarakat Indonesia memiliki smartphone. Dan suvei yang dilakukan oleh Asosiasi Penyelenggara Jasa Internet Indonesia (APJII) tahun 2018, persentase pengguna internet di Indonesia meningkat. Pada tahun 2017, pengguna internet di Indonesia adalah 54,68 \% sedangkan pada tahun 2018 meningkat menjadi $64,8 \%$.

Berdasarkan hasil survei tersebut, guru diharuskan untuk membuat inovasi baru dalam pembelajaran dengan memanfaatkan teknologi. Pemanfaatan teknologi adalah salah satu cara untuk guru dapat mengembangkan inovasi baru supaya bisa diterapkan saat proses pembelajaran. Namun, masih banyak guru yang belum memanfaatkan teknologi secara maksimal. Padahal, penggunaan teknologi saat ini sudah semakin pesat. Pembelajaran yang baik adalah pembelajaran yang mampu memaksimalkan penggunaan 
Pengembangan Bahan Ajar Problem Based Learning untuk Pembelajaran Daring dengan Platform Edmodo, Ana Fitri Aeni, Anwar Mutaqin, Yani Setiani

dari fasilitas (sarana dan prasarana) yang tersedia, yang mana dalam hal ini adalah penggunaaan teknologi. Namun, keadaan di lapangan saat ini, masih banyak yang menggunakan bahan ajar berupa buku tebal yang membuat siswa cepat merasa bosan karena model bahan ajar yang kurang menarik.

Saat ini adanya pandemi Covid-19 atau corona virus yang terjadi secara global, menyebabkan tidak adanya lagi kegiatan belajar-mengajar di sekolah seperti biasa. Adanya pandemi ini mengharuskan siswa untuk belajar di rumah secara daring atau online. Tidak adanya pembelajaran secara langsung dengan guru menyebabkan banyak siswa yang merasa kesulitan dalam belajar. Banyak juga siswa yang mengeluhkan bosan untuk berlama-lama mengikuti pembelajaran secara daring atau online. Menurut Dharmawan (2014), pembelajaran online adalah salah satu bentuk inovasi pembelajaran saat ini. Pembelajaran online juga dikenal dengan istilah pembelajaran jarak jauh atau distance learning. Untuk pembelajaran secara daring ini, terdapat beberapa hal yang perlu diperhatikan, salah satunya adalah ketersediaan sarana dan prasarana yang menunjang untuk kegiatan pembelajaran (Wahyono et al., 2020). Pembelajaran online dapat diakses melalui laptop ataupun smartphone. Namun, pengguna smartphone di Indonesia masih kurang dalam hal belajar. Berdasarkan survei yang dilakukan oleh KOMINFO terhadap aktifivitas penggunaan smartphone oleh individu yang terhubung dengan internet adalah 65,29\% untuk hiburan dan 27,51\% untuk belajar (Kominfo, 2017).

Penggunaan LMS (Learning Management System) sangat membantu guru untuk mengajar secara daring atau online. Salah satu LMS (Learning Management System) yang dapat digunakan guru untuk mengajar secara daring atau online adalah Edmodo. Edmodo adalah salah satu platform pembelajaran online yang mirip seperti media sosial Facebook. Dengan adanya Edmodo, guru dapat membuat dan mengelola sebuah kelas virtual, dimana dalam kelas tersebut tidak hanya melibatkan guru dan siswa saja, tetapi juga melibatkan orang tua.

Edmodo cocok digunakan karena berbasis pada TIK dan sesuai dengan perkembangan era digital saat ini. Edmodo memiliki akses yang cepat dan penggunaannya lebih mudah dibandingkan dengan LMS lainnya dan didesain untuk pembelajaran berbasis sekolah dan dapat diakses secara gratis (Ekayati, 2017). Pada platform Edmodo terdapat fitur open source. Dalam fitur ini, kita bisa mengakses materi yang ingin dipelajari seara gratis. Selain itu, pengumpulan tugas menggunakan edmodo, bisa dilakukan dengan mengumpulkan softcopy. Hal ini tentunya berdampak baik bagi lingkungan, karena mengurangi penggunaan limbah kertas. Penggunaan edmodo dapat membantu siswa mengurangi penggunaan internet yang negatif menjadi lebih positif.

Dari permasalahan yang telah dikemukakan, perlu dikembangkan bahan ajar yang cocok untuk menggali minat siswa dalam belajar matematika dan juga cocok untuk diterapkan pada situasi seperti saat ini. Oleh karena itu perlu dilakukan penelitian dalam mengembangkan bahan ajar berbasis Problem Based Learning untuk pembelajaran daring dengan platform Edmodo.

\section{METODE}

Desain penelitian ini adalah penelitian dan pengembangan atau Research and Development (R\&D). 
Penelitian ini menghasilkan suatu produk berbasis Problem Based Learning pada pokok bahasan materi Persamaan Linier Satu Variabel (PLSV) yang akan digunakan dalam proses pembelajaran. Menurut Sugiyono (2015) desain penelitian dan pengembangan adalah desain yang digunakan untuk menghasilkan produk tertentu dan menguji keefektifan produk tersebut. Subjek yang digunakan dalam penelitian ini adalah siswa SMP BINA CIPTA KARYA (BCK) CILEGON kelas VII-A. Subyek akan diambil 10 orang siswa untuk dijadikan sebagai subyek penelitian. Pengambilan subjek penelitian pada siswa dipilih secara acak. Menurut Sugiyono (2015), terdapat 10 langkah yang diperlukan dalam penelitian R\&D, yaitu:

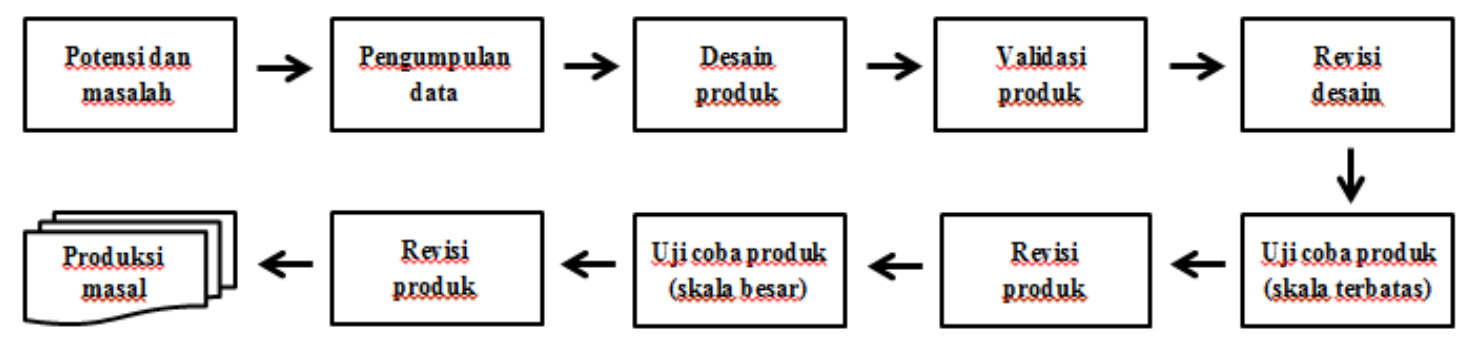

Gambar 1. Langkah-Langkah Penelitian R\&D

Pengembangan bahan ajar yang dibuat hanya pada sampai langkah keenam, yaitu uji coba produk skala terbatas. Karena bahan ajar ini hanya akan diuji coba pada 10 orang siswa sebagai subyek penelitiannya. Selain itu, bahan ajar ini tidak untuk diedarkan secara luas. Instrumen penelitian adalah alat yang digunakan untuk mengumpulkan data. Instrumen yang digunakan dalam penelitian ini, yaitu: instrumen tes dan instrument non-tes. Instrumen tes yang digunakan dalam penelitian ini berbentuk soal uraian dan pilihan ganda. Instrumen tes digunakan untuk mengetahui hasil belajar siswa setelah menggunakan bahan ajar. Sedangkan instrumen non-tes yang digunakan adalah angket. Menurut Sugiyono (2015) angket adalah teknik pengumpulan data yang digunakan dengan cara memberi seperangkat pertanyaan atau pernyataan tertulis kepada responden untuk dijawab. Angket dalam penelitian ini terdiri dari:

\section{Angket uji ahli materi}

Tabel 1. Indikator Penilaian Angket Uji Ahli Materi

\begin{tabular}{|c|c|}
\hline Kriteria Penilaian & Indikator Penilaian \\
\hline \multirow{3}{*}{ Aspek kelayakan isi } & Kesesuaian materi dengan SK dan KD \\
\cline { 2 - 2 } & Keakuratan materi \\
\cline { 2 - 2 } Aspek kelayakan penyajian & Keterampilan \\
\cline { 2 - 2 } & Teknik penyajian \\
\cline { 2 - 2 } & Pendukung penyajian \\
\hline \multirow{4}{*}{ Aspek kelayakan bahasa } & Kelengkapan penyajian \\
\cline { 2 - 2 } & Kemas \\
\cline { 2 - 2 } & Kesesuaian dengan kaidah bahasa \\
\cline { 2 - 2 } & Penggunaan istilah, symbol, atau ikon \\
\hline
\end{tabular}


Pengembangan Bahan Ajar Problem Based Learning untuk Pembelajaran Daring dengan Platform Edmodo, Ana Fitri Aeni,

Angket Uji Ahli Media

Tabel 2. Indikator Penilaian Angket Uji Ahli Media

\begin{tabular}{|c|c|}
\hline Kriteria Penilaian & Indikator Penilaian \\
\hline \multirow{3}{*}{ Aspek kelayakan kegrafikan } & Desain cover \\
\cline { 2 - 2 } & Desain Powerpoint \\
\cline { 2 - 2 } & Video \\
\hline
\end{tabular}

\section{Angket Respon Siswa}

Tabel 3. Indikator Penilaian Angket Respon Siswa

\begin{tabular}{|c|c|}
\hline Kriteria Penilaian & Indikator Penilaian \\
\hline \multirow{2}{*}{ Respon Siswa } & Materi \\
\cline { 2 - 2 } & Bahasa \\
\cline { 2 - 2 } & Ketertarikan \\
\hline
\end{tabular}

Analisis data pada instrumen tes untuk menghitung persentase kriteria ketuntasan hasil belajar siswa, dihitung menggunakan rumus:

$$
\text { Persentase hasil belajar }(p)=\frac{\text { banyak siswa tuntas }}{\text { jumlah siswa }} \times 100 \%
$$

Adapun kriteria persentase hasil belajar siswa menurut Arikunto (2009) sebagai berikut:

Tabel 4. Kriteria Persentase Ketuntasan Hasil Belajar Siswa

\begin{tabular}{|c|l|}
\hline Kriteria (dalam persen) & Klasifikasi \\
\hline $80-100$ & Baik Sekali \\
\hline $66-79$ & Baik \\
\hline $56-65$ & Cukup \\
\hline $40-55$ & Kurang \\
\hline$\leq 39$ & Gagal \\
\hline
\end{tabular}

Pada instrumen non-tes, skala yang digunakan adalah skala Likert. Untuk mendeskripsikan hasil angket, maka hasilnya dihitung menggunakan rumus:

$$
\text { Persentase }=\frac{\text { Skor mentah }}{\text { Skor ideal }} \times 100 \%
$$

Adapun kriteria persentase angket menurut Riduwan (2010) sebagai berikut:

Tabel 5. Kriteria Angket

\begin{tabular}{|c|c|}
\hline Kriteria (dalam persen) & Klasifikasi \\
\hline $0 \leq P<20$ & Sangat Tidak Layak \\
\hline $20 \leq P<40$ & Tidak Layak \\
\hline $40 \leq P<60$ & Cukup Layak \\
\hline $60 \leq P<80$ & Layak \\
\hline $80 \leq P \leq 100$ & Sangat Layak \\
\hline
\end{tabular}

\section{HASIL DAN DISKUSI}

Desain pengembangan yang digunakan dalam penelitian ini adalah desain pengembangan R\&D yang diadaptasi dari Sugiyono. Terdapat enam prosedur atau langkah yang digunakan dalam desain penelitian ini, yaitu menentukan potensi dan masalah, mengumpulkan informasi, desain produk, uji validasi, revisi 
atau perbaikan produk dan yang terakhir adalah uji coba produk dengan skala terbatas.

Mencari potensi dan masalah adalah hal yang mendasari pengembangan bahan ajar ini. Potensi dan masalah yang didapat menunjukkan bahwa, karena terjadinya pandemi saat ini penggunaan platform pembelajaran dan bahan ajar yang menunjang kegiatan belajar siswa yang dilakukan secara daring di rumah sangatlah diperlukan. Berdasarkan informasi yang diperoleh, saat ini di bahan ajar yang digunakan di sekolah adalah buku paket. Dan karena saat ini terjadi pandemi Covid-19, maka kegiatan pembelajaran dilakukan secara online. Untuk pembelajaran online, guru biasanya menggunakan Whatsapp atau Classsroom untuk membagikan tugas, materi atau link video youtube. Untuk itu, penelitian ini akan membuat bahan ajar Problem Based Learning. Untuk platform pembelajaran dipilih Edmodo, karena fitur pada Edmodo lebih lengkap dibandingkan dengan Classroom sehingga Edmodo lebih cocok digunakan untuk pembelajaran e-learning (Nurhayati et al., 2019).

Data atau informasi terkait materi PLSV dan pengembangan bahan ajar ini diperoleh dengan mengumpulkan referensi atau sumber dari buku-buku, internet, pendapat dari guru matematika SMP dan dosen pembimbing. Bahan ajar Problem Based Learning ini didesain berbentuk powerpoint. Desain awal bahan ajar Problem Based Learning terdiri dari beberapa slide, yaitu: cover awal powerpoint, menu, KD dan IPK, video pembelajaran, tokoh matematika, kuis, evaluasi dan terakhir mini game. Dalam proses pembuatan bahan ajar ini diperlukan beberapa software untuk merealisasikan desain yang dibuat. Software yang digunakan antara lain: Ms. Powerpoint 2016, Movavi Video Editor Plus, Adobe Photoshop, Paint, dan kamera handphone. Desain awal bahan ajar sebelum dilakukan validasi oleh penguji ahli materi dan media dapat dilihat pada gambar 2 .

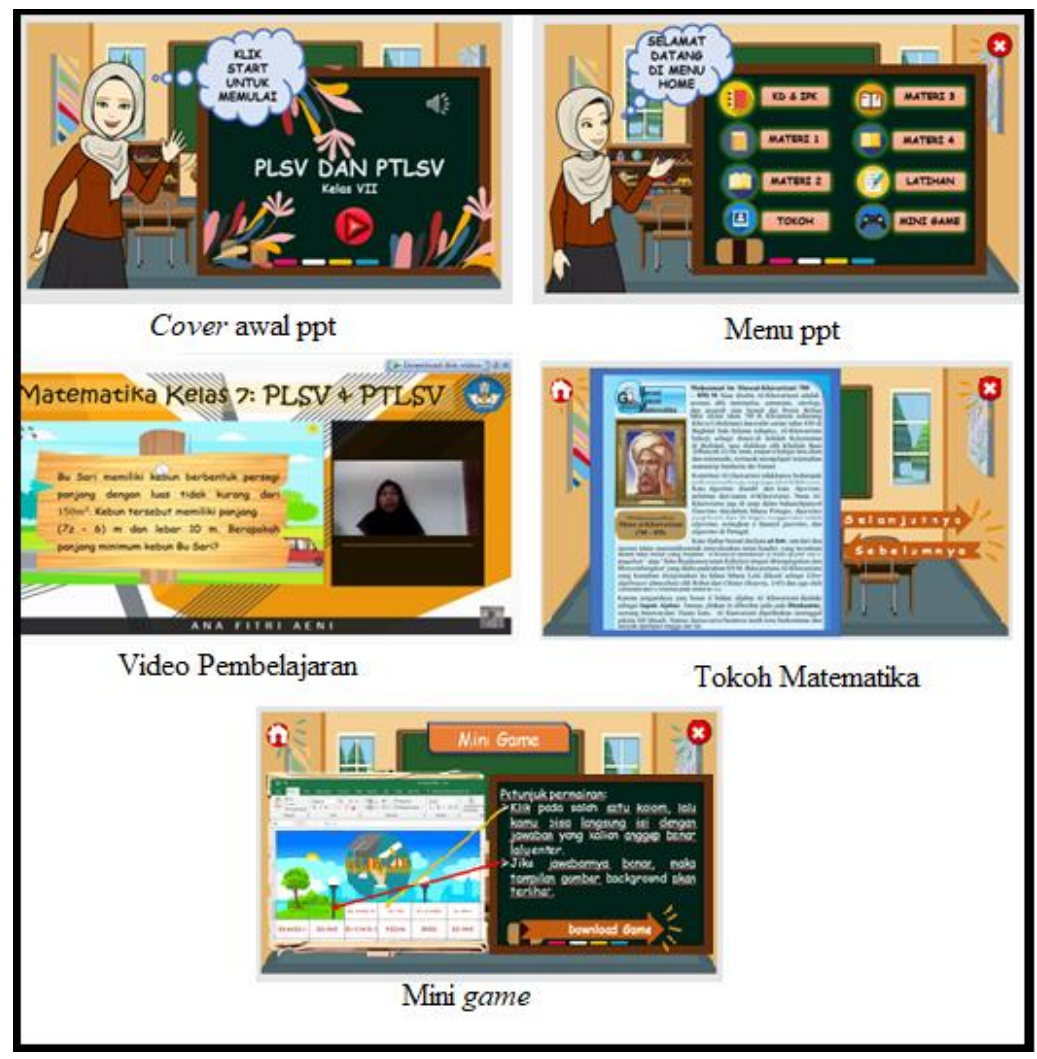

Gambar 2. Desain awal bahan ajar 
Pengembangan Bahan Ajar Problem Based Learning untuk Pembelajaran Daring dengan Platform Edmodo, Ana Fitri Aeni, Anwar Mutaqin, Yani Setiani

Setelah desain bahan ajar dibuat, langkah selanjutnya adalah dilakukan uji validasi oleh para ahli materi dan para ahli media. Berikut ini adalah hasil validasi yang dilakukan oleh penguji ahli materi:

Tabel 6. Hasil validasi uji ahli materi

\begin{tabular}{|c|c|c|c|}
\hline No. & Indikator Penilaian & Persentase (\%) & Kriteria \\
\hline 1 & $\begin{array}{c}\text { Kesesuaian materi } \\
\text { dengan SK dan KD }\end{array}$ & 79.2 & Cukup Valid \\
\hline 2 & Keakuratan Materi & 87.5 & Sangat Valid \\
\hline 3 & Keterampilan & 75 & Cukup Valid \\
\hline 4 & Teknik penyajian & 81.25 & Cukup Valid \\
\hline 5 & $\begin{array}{c}\text { Pendukung } \\
\text { penyajian }\end{array}$ & 87.5 & Cungat Valid \\
\hline 6 & $\begin{array}{c}\text { Kelengkapan } \\
\text { penyajian }\end{array}$ & 83.3 & Cukup Valid \\
\hline 7 & Lugas & 75 & Cukup Valid \\
\hline 8 & Komunikatif & 75 & Cukup Valid \\
\hline 9 & $\begin{array}{c}\text { Kesesuaian dengan } \\
\text { kaidah bahasa }\end{array}$ & 75 & Cukup Valid \\
\hline 10 & $\begin{array}{c}\text { Penggunaan istilah, } \\
\text { symbol, atau ikon }\end{array}$ & 81.25 & $\mathbf{8 1 . 2 5}$ \\
\hline \multicolumn{3}{|c|}{ Persentase Akhir } &
\end{tabular}

Hasil dari pengujian oleh ahli materi diperoleh skor 156 poin dari total skor 192 poin dengan rata-rata persentase akhir yaitu 81.25\%. sehingga, bahan ajar Problem Based Learning ini termasuk pada kriteria "cukup valid". Sehingga dapat disimpulkan bahwa rata-rata penguji ahli materi menjawab setuju jika materinya sudah sesuai dan akurat dengan SK dan KD. Pada aspek kelayakan penyajian, rata-rata penguji ahli menjawab setuju jika bahan ajar ini sudah memuat pembahasan materi dan soal-soal terkait PBL; penggunaan simbol, ikon atau istilah dalam matematika sudah tepat; dan dalam penyampaian materi, bahasa yang digunakan sudah baik. Komentar yang diberikan oleh penguji ahli materi adalah secara umum, bahan ajar ini sudah menarik. Namun, perdalam lagi definisi dari PLSV, berikan pemisalan yang dapat membuat siswa mampu membedakan PLSV dan yang bukan PLSV.

Selanjutnya adalah hasil validasi yang dilakukan oleh penguji ahli media sebagai berikut:

Tabel 7. Hasil validasi uji ahli media

\begin{tabular}{|c|c|c|c|}
\hline No. & Indikator Penilaian & Persentase (\%) & Kriteria \\
\hline 1 & Desain cover & 78.125 & Cukup Valid \\
\hline 2 & Desain Powerpoint & 81.25 & Cukup Valid \\
\hline 3 & Video & 77.5 & Cukup Valid \\
\hline & Persentase Akhir & $\mathbf{7 9 . 1 6 6 6 6 6 6 7}$ & Cukup Valid \\
\hline
\end{tabular}

Pada uji ahli media diperoleh skor 95 poin dari total skor 120 poin dengan rata-rata persentase akhir 79.16\% sehingga, bahan ajar Problem Based Learning ini termasuk pada kriteria “cukup valid”. Sehingga dapat disimpulkan bahwa rata-rata penguji ahli media menjawab setuju jika desain cover; desain powerpoint; dan video yang disajikan dalam bahan ajar memiliki tampilan yang menarik. Sehingga siswa 
tidak merasa bosan menggunakannya. Komentar yang diberikan oleh penguji ahli media adalah ilustrasi dan video pembelajaran sudah baik dan menarik. Namun, untuk audio pada video pembelajaran harus diperjelas lagi, karena terdapat beberapa penjelasan yang kurang terdengar dengan jelas.

Setelah dilakukan pengujian oleh para ahli materi dan media, langkah selanjutnya adalah dilakukan perbaikan atau revisi berdasarkan komentar para ahli. Revisi atau perbaikan dilakukan guna memperbaiki bahan ajar sebelum dilakukan uji coba secara terbatas. Berikut ini adalah desain akhir bahan ajar setelah dilakukan revisi berdasarkan komentar para ahli:

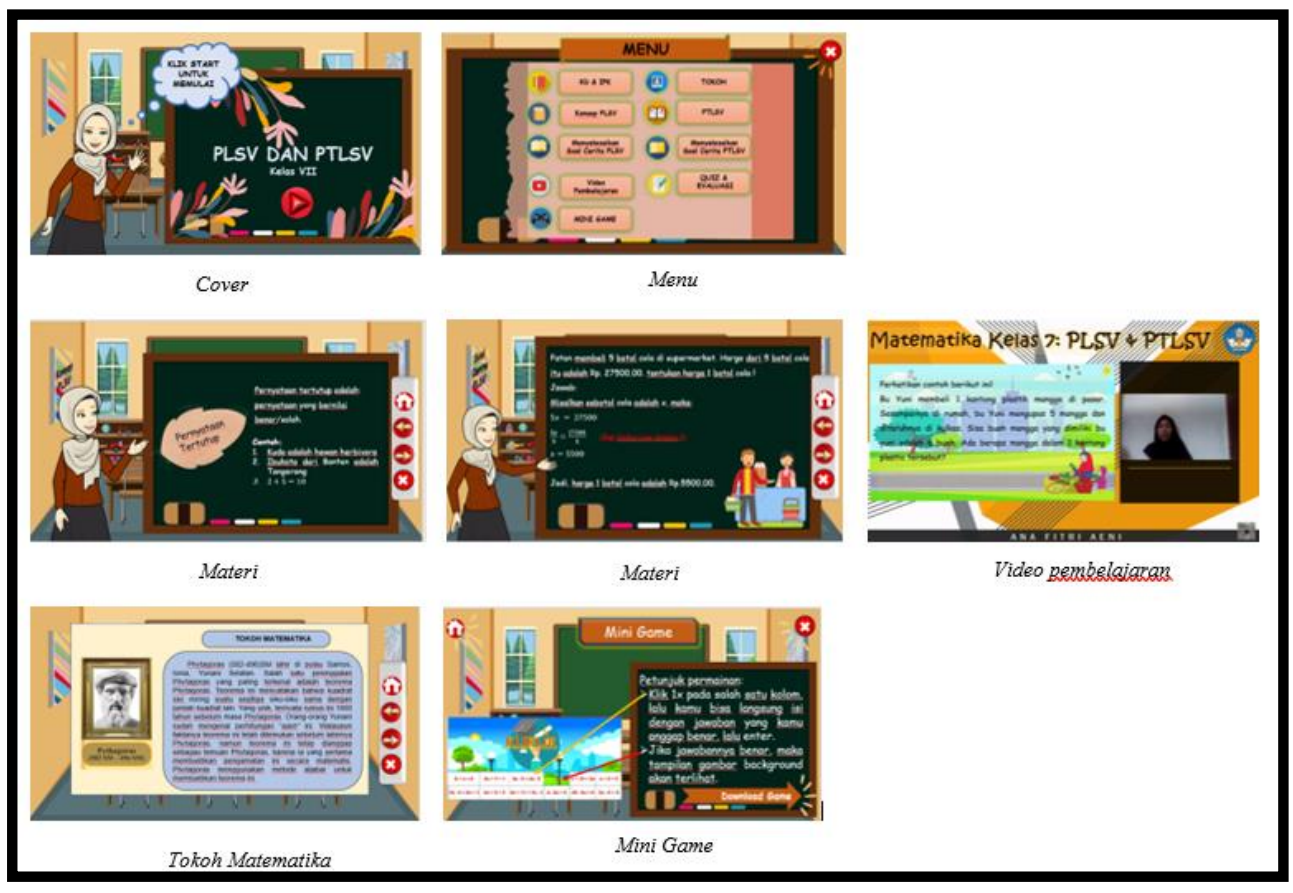

Gambar 2. Desain akhir bahan ajar

Setelah bahan ajar selesai di revisi, bahan ajar akan diujicobakan dalam skala kecil atau biasa disebut uji coba terbatas. Bahan ajar akan ini diujicobakan kepada 10 orang siswa SMP kelas VII-A SMP BINA CIPTA KARYA (BCK) CILEGON. Pada uji coba secara terbatas ini, LMS yang dipilih adalah Edmodo. Saat ujicoba bahan ajar, ada beberapa siswa yang kebingungan dalam menggunakan Edmodo. Sehingga, peneliti mengambil langkah untuk membuat tutorial penggunaan aplikasi Edmodo. Hal ini dilakukan peneliti agar siswa memahami cara menggunakan aplikasi tersebut. Kendala lain adalah, ada beberapa siswa yang kesulitan saat menonton video pembelajaran di Youtube dan mengisi quiz. Ini dikarenakan beberapa siswa tersebut terkendala di masalah kuota internet. Ini mengakibatkan beberapa siswa tertinggal dalam memperoleh informasi baru dan terlambat dalam mengumpulkan tugas. Hal ini sesuai dengan penelitian yang dilakukan oleh Handarini \& Wulandari (2020), bahwa dalam pembelajaran daring sarana dan prasarana seperti laptop, smartphone dan internet sangat dibutuhkan. Tapi, masih ada saja siswa yang terkendala saat melakukan pembelajaran daring dikarenakan belum memiliki sarana dan prasarana tersebut.

Setelah dilakukan pembelajaran secara daring melalui platform Edmodo, guru memberikan tes dan 
Pengembangan Bahan Ajar Problem Based Learning untuk Pembelajaran Daring dengan Platform Edmodo, Ana Fitri Aeni, Anwar Mutaqin, Yani Setiani

angket respon siswa untuk mengetahui hasil belajar dan bagaimana respon siswa terhadap pembelajaran menggunakan bahan ajar ini. Berikut ini adalah hasil angket respon siswa yang disajikan dalam tabel:

Tabel 8. Hasil angket respon siswa

\begin{tabular}{|c|c|c|}
\hline Siswa Ke - & Persentase (\%) & Kriteria \\
\hline Siswa ke- 01 & 71.875 & Layak \\
\hline Siswa ke- 02 & 75 & Layak \\
\hline Siswa ke- 03 & 81.25 & Layak \\
\hline Siswa ke- 04 & 81.25 & Layak \\
\hline Siswa ke- 05 & 81.25 & Layak \\
\hline Siswa ke- 06 & 68.75 & Layak \\
\hline Siswa ke- 07 & 71.875 & Layak \\
\hline Siswa ke- 08 & 75 & Layak \\
\hline Siswa ke- 09 & 71.875 & Layak \\
\hline Siswa ke- 10 & 71.875 & Layak \\
\hline PERSENTASE AKHIR & $\mathbf{7 5}$ & Layak \\
\hline
\end{tabular}

Berdasarkan pada Tabel 8, diperoleh skor 240 poin dari total skor 320 poin dengan presentase akhir yang didapat adalah $75 \%$ dari rentang $60 \leq \mathrm{P}<80$ yang termasuk pada kriteria "layak". Angket respon siswa ini memiliki 3 indikator. Indikator pertama adalah materi, indikator kedua adalah bahasa dan indikator ketiga adalah ketertarikan. Pada indikator pertama yaitu indikator materi yang terdapat pada pernyataan nomor 2, 3, 4 dan 5, diperoleh persentase skor 74,37\% yang termasuk pada kriteria "layak". Secara garis besar dapat disimpulkan bahwa rata-rata siswa setuju bahan ajar ini memuat materi dan kuis yang berkaitan dengan kehidupan sehari-hari. Ini akan memudahkan siswa dalam mempelajari materi yang ada dalam bahan ajar ini. Hal ini sejalan dengan penelitian yang dilakukan oleh Saleh (2013) yang menyatakan bahwa PBL dapat memudahkan dalam siswa dalam memahami suatu masalah dan menghubungkannya dengan realitas permasalahan yang ada dalam masyarakat.

Pada indikator kedua yaitu indikator bahasa yang terdapat pada pernyataan nomor 6 , diperoleh persentase skor yaitu 70\% sehingga mendapat kriteria "layak". Pada indikator ketiga ini, rata-rata siswa menjawab setuju jika bahasa yang digunakan dalam bahan ajar ini mudah dipahami oleh siswa. Penggunaan bahasa yang mudah dipahami, akan membuat pembelajaran menjadi tidak membosankan bagi siswa dan siswa akan memahami materi pembelajaran dengan baik.

Indikator ketiga adalah indikator ketertarikan yang terdapat pada pernyataan nomor 1,7 dan 8 dan persentase skor yang diperoleh adalah $76,6 \%$ dan termasuk pada kriteria "layak". Pada indikator ketertarikan, rata-rata siswa menjawab sangat antusias dan senang menggunakan bahan ajar Problem Based Learning ini. Karena tampilan dari bahan ajar ini menarik, sehingga antusias mereka saat belajar matematika menggunakan bahan ajar Problem Based Learning ini membuat mereka menjadi tidak bosan. Hal ini sesuai 
dengan penelitian yang dilakukan oleh Wahyudi, dkk (2014) yang menunjukan bahwa penggunaan bahan ajar akan dapat meningkatkan minat siswa melalui aktivitas siswa yang terdapat didalam bahan ajar, sehingga siswa tidak merasa bosan dengan materi yang disajikan.

Saat ini, materi yang dibahas adalah Persamaan Linier Satu Variabel (PLSV). Pada pembelajaran sebelumnya, siswa sudah menerima materi tentang konsep aljabar. Pada proses ini terjadi asimilasi dan akomodasi. Hal ini sesuai dengan teori Piaget, yaitu akan terjadi proses dimana siswa membedakan prinsip aljabar dengan PLSV. Setelah itu, siswa akan menerapkan atau menggunakan prinsip-prinsip PLSV untuk menyelesaikan sebuah permasalahan. Dalam bahan ajar ini, juga terdapat pembahasan-pembahasan soal terkait materi PLSV. Guru hanya berperan sebagai pembimbing dan fasilitator bagi siswa. Siswa bisa bertanya pada guru jika terdapat hal yang tidak mereka pahami. Hal ini sesuai dengan teori konstruktivisme menurut Vygotsky, dimana guru memberikan sejumlah bantuan pada siswa selama tahap pembelajaran (scaffolding). Bantuan yang diberikan dapat berupa petunjuk, memberikan contoh atau menguraikan masalah dalam langkah penyelesaian. Hal ini juga sejalan dengan penelitian yang dilakukan oleh Larasati \& Mampouw (2018) yang menyatakan bahwa pemberian scaffolding dapat membantu siswa memperbaiki kesalahan mereka dalam menyelesaikan soal cerita materi perbandingan.

Guru memberikan kesempatan pada siswa untuk menggali informasi-informasi yang diperoleh dengan saling bertanya sesama teman atau bertanya pada guru. Dengan adanya aktivitas tersebut siswa akan terlatih untuk belajar secara aktif untuk menemukan ide-ide baru dalam menyelesaikan sebuah permasalahan. Ini sesuai dengan pendapat dari Inhelder \& Piaget (1958) yang menekankan pentingnya peran siswa untuk berpartisipasi aktif dalam belajar untuk menemukan suatu pemahaman konsep agar mencapai sebuah kesimpulan atau suatu pemecahan masalah.

Setelah siswa mempelajari materi dari bahan ajar, selanjutnya siswa akan diberikan tes. Dari 10 siswa yang berpartisipasi, terdapat 3 siswa yang dikategorikan tidak lulus. Siswa yang tidak lulus adalah siswa04, siswa-06 dan siswa-07. Berikut ini adalah lembar jawaban siswa-04:

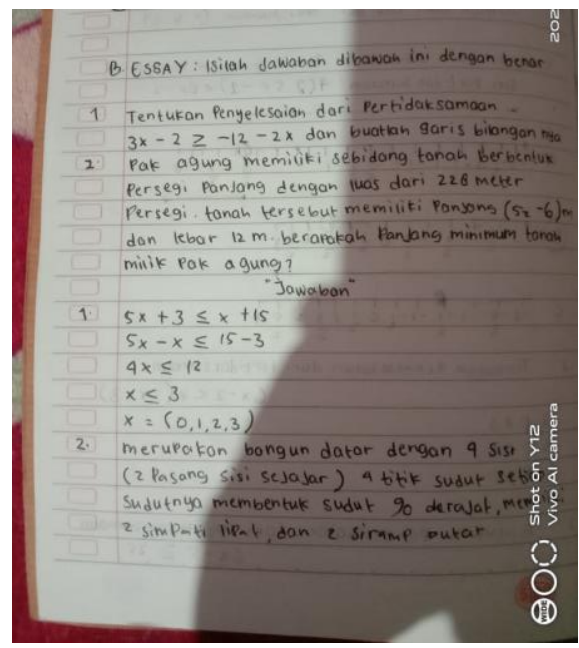

Gambar 3. Jawaban Siswa-04

Pada lembar jawaban siswa-04 nomor 1, siswa tersebut menuliskan soal yang benar namun, 
Pengembangan Bahan Ajar Problem Based Learning untuk Pembelajaran Daring dengan Platform Edmodo, Ana Fitri Aeni, Anwar Mutaqin, Yani Setiani

menjawab pertanyaan dengan jawaban yang salah. Sedangkan pada nomor 2, siswa salah dalam menafsirkan maksud dari soal. Berikutnya adalah lembar jawaban siswa-06:

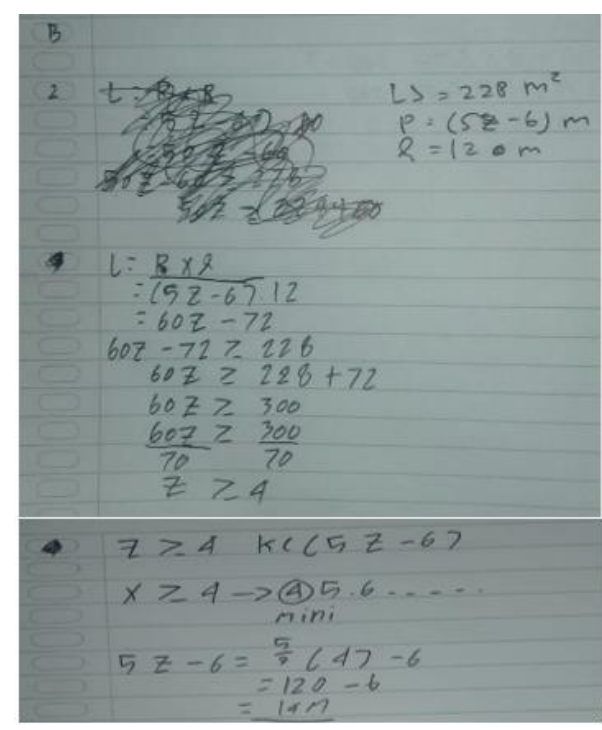

Gambar 4. Jawaban Siswa-06

Pada lembar jawaban siswa-06 nomor 1, siswa tersebut tidak menuliskan jawaban dari pertanyaan yang diberikan. Sedangkan pada nomor 2, siswa tidak menuliskan terlebih dahulu apa yang diketahui dan ditanyakan dari soal. Siswa langsung menuliskan penyelesaian dari soal nomor 2. Namun, sangat disayangkan saat mengerjakan nomor 2 siswa tidak berhasil menjawab pertanyaan yang diberikan dengan benar, padahal langkah penyelesaian yang dituliskan sudah benar. Berikutnya adalah lembar jawaban siswa07:

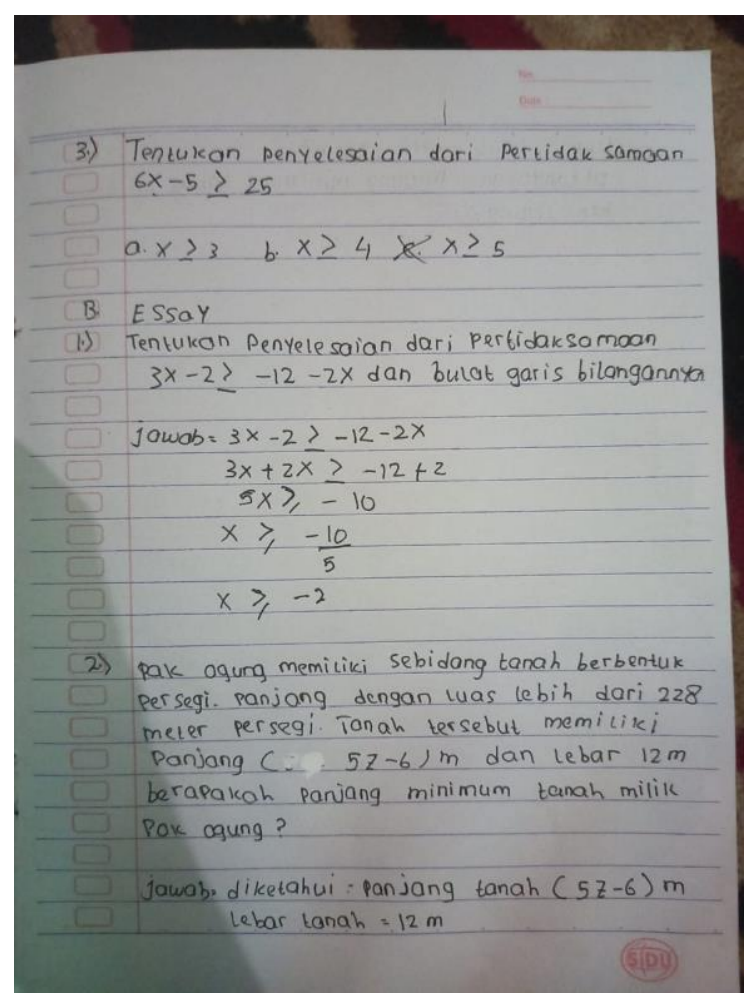

Gambar 5. Jawaban Siswa-07 
Pada lembar jawaban siswa-07 nomor 1, siswa tersebut berhasil menjawab pertanyaan yang diberikan, namun saat diminta membuat garis bilangan, siswa masih kesulitan. Sedangkan pada soal nomor 2, siswa menuliskan terlebih dahulu apa yang diketahui dan ditanyakan dari soal. Namun siswa tidak bisa melanjutkan bagaimana cara menyelesaikan permasalahan tersebut. Adapun persentase ketuntasan hasil belajar siswa disajikan dalam tabel di bawah ini:

Tabel 9. Hasil Belajar Siswa

\begin{tabular}{|l|l|}
\hline Jumlah subjek penelitian & 10 siswa \\
\hline Jumlah siswa yang tuntas & 7 siswa \\
\hline Jumlah siswa yang tidak tuntas & 3 siswa \\
\hline Persentase hasil belajar & $70 \%$ \\
\hline
\end{tabular}

Berdasarkan Tabel 9, di atas jumlah siswa yang tuntas adalah 7 siswa dari total 10 siswa. Sehingga persentase hasil belajar yang diperoleh adalah 70\% dan termasuk pada kriteria "baik". Menurut Agustina \& Vahlia (2016) penggunaan bahan ajar matematika ekonomi berbasis masalah pada kelas A memperoleh rata-rata nilai yang lebih tinggi dibandingkan kelas B. Ini juga sesuai dengan penelitian yang dilakukan oleh Wimpy, dkk (2017) media pembelajaran dikatakan efektif dilihat dari persentase hasil belajar. Pemberian tes ini dilakukan untuk menguatkan kembali pemahaman siswa tentang materi PLSV. Hal ini sejalan dengan teori belajar oleh Ausubel. Dimana materi yang sudah didapat oleh siswa akan digunakan sebagai informasi dalam menyelesaikan suatu soal atau permasalahan. Melalui informasi yang didapat, siswa akan memproses informasi tersebut dan mengaitkan dengan informasi yang sudah didapat sebelumnya. Namun, pada tes yang diujicobakan terdapat tiga siswa yang tidak lulus.

\section{KESIMPULAN}

Desain penelitian ini adalah penelitian dan pengembangan atau Research and Development (R\&D). Dan langkah-langkah yang diperlukan dalam penelitian Research and Development (R\&D) ini adalah: menentukan potensi dan masalah, mengumpulkan informasi, membuat desain produk, validasi ahli, revisi produk dan yang terakhir adalah uji coba terbatas. Untuk uji ahli materi dilakukan oleh dua orang dosen Pendidikan Matematika UNTIRTA sedangkan untuk uji ahli media dilakukan oleh seorang dosen Pendidikan Matematika UNTIRTA dan seorang guru dari MTs Al-Khaeriyah Pekalongan. Untuk uji ahli terbatas diambil sampel sebanyak 10 orang siswa kelas VII-A SMP BCK CILEGON.

Hasil dari uji ahli materi yang telah dilakukan menempatkan bahwa bahan ajar Problem Based Learning ini "cukup valid" untuk digunakan dengan hasil perhitungan persentase skor akhir yang diperoleh adalah $81,25 \%$ dari rentang 70,01\% - 85,00\%. Sedangkan hasil dari uji ahli media menempatkan bahwa bahan ajar Problem Based Learning ini "cukup valid" untuk digunakan dengan hasil perhitungan persentase skor akhir yang diperoleh adalah adalah 79,17\% dari rentang 70,01\%-85,00\%.

Hasil dari angket siswa yang telah diujikan menempatkan bahwa bahan ajar problem based learning ini mendapat kriteria "layak" karena mendapat respon yang positif dari siswa dengan hasil perhitungan persentase skor akhir yang diperoleh adalah $75 \%$ dari rentang $60 \leq \mathrm{P}<80$. Dan untuk persentase hasil 
Pengembangan Bahan Ajar Problem Based Learning untuk Pembelajaran Daring dengan Platform Edmodo, Ana Fitri Aeni,

belajar yang diperoleh adalah 70\% dan termasuk pada kriteria "baik", karena persentase skor akhir yang diperoleh terdapat pada rentang $66 \%-79 \%$.

\section{REFERENSI}

Agustina, R., \& Vahlia, I. (2016). Pengembangan Bahan Ajar Berbasis Masalah Pada Mata Kuliah Matematika Ekonomi Program Studi Pendidikan Matematika. Aksioma, 5(2), 152-160.

Arikunto, S. (2009). Dasar-Dasar Evaluasi Pendidikan. Bumi Aksara.

Ekayati Rini. (2017). Optimalisasi Aplikasi Edmodo dalam Meningkatkan Kemandirian belajar dan Kesadaran Berbahasa Mahasiswa Pada Mata Kuliah Literaty Criticism di FKIP UMSU. EduTech, $3(1), 148-165$.

Depdiknas. (n.d.). Panduan Pengembangan Bahan Ajar. Depdiknas.

Dharmawan. (2014). Pengembangan E-Learning: Teori Dan Desain. Remaja Rosdakarya.

Handarini, O. I., \& Wulandari, S. S. (2020). Pembelajaran Daring Sebagai Upaya Study From Home (SFH) Selama Pandemi Covid 19. Jurnal Pendidikan Administrasi Perkantoran (JPAP), 8(3). https://doi.org/10.1093/fampra/cmy005

Inhelder, B., \& Piaget, J. (1958). The Growth of Logical Thingking From Childhood to Adolescence. Basic Books.

Kemendikbud. (2013). Permedikbud Nomor 65 Tahun 2013 Tentang Standar Proses. Kemendikbud.

Khotimah, K., Siroj, R. A., \& Basir, D. (2012). Pengembangan Bahan Ajar Matematika Mengacu Pada Pembelajaran Berbasis Masalah Bagi Siswa Kelas Viii Sekolah Menengah Pertama Negeri 1 Rambang Kuang. Jurnal Pendidikan Matematika, 6(1). https://doi.org/10.22342/jpm.6.1.4090.19-34

Kominfo. (2017). Survei Penggunaan Tik Serta Implikasinya Terhadap Aspek Sosial Budaya Masyarakat. Pusat Penelitian Dan Pengembangan Aplikasi Informatika Dan Informasi Dan Komunikasi Publik.

Larasati, Y., \& Mampouw, H. L. (2018). Pemberian scaffolding untuk menyelesaikan soal cerita materi perbandingan senilai dan berbalik nilai. Math Didactic: Jurnal Pendidikan Matematika, 4(1), 47-56. https://doi.org/10.33654/math.v4i1.85

Nurhayati, D., Az-zahra, H. M., \& Herlambang, A. D. (2019). Evaluasi User Experience Pada Edmodo Dan Google Classroom Menggunakan Technique for User Experience Evaluation in E-Learning ( TUXEL ) ( Studi Pada SMKN 5 Malang ). Jurnal Pengembangan Teknologi Informasi Dan Ilmu Komputer, 3(4), 3771-3780. http://j-ptiik.ub.ac.id

Riduwan. (2010). Dasar-Dasar Statistika. Alfabeta.

Saleh, M. (2013). Strategi Pembelajaran Fiqh Dengan Problem-Based Learning. Jurnal Ilmiah Didaktika, 14(1), 190-220. https://doi.org/10.22373/jid.v14i1.497

Sugiyono. (2015). Metode Penelitian Pendidikan Pendekatan Kuantitatif, Kualitatif Dan R\&D. Alfabeta.

Surmiyati, Kritayulita, \& Patmi, S. (2014). Analisis Kemampuan Kognitif Dan Kemampuan Afektif Terhadap Kemampuan Psikomotor Setelah Penerapan Ktsp. Beta, 7(1), 25-36.

Wahyono, P., Husamah, H., \& Budi, A. S. (2020). Guru profesional di masa pandemi COVID-19: Review implementasi, tantangan, dan solusi pembelajaran daring. Jurnal Pendidikan Profesi Guru, 1(1), 51 65. http://ejournal.umm.ac.id/index.php/jppg/article/view/12462

Wahyudi, B. S., Hariyadi, S., \& Hariani, S. A. (2014). Pengembangan Bahan Ajar Berbasis Model Problem 
Based Learning Pada Pokok Bahasan Pencemaran Lingkungan Untuk Meningkatkan Hasil Belajar Siswa Kelas X Sma Negegi Grujugan Bondowoso. Pancaran, 3(3), 83-92.

Wimpy, Mulyani, S., \& Ashadi. (2017). Pengembangan Media Berbasis Aplikasi Pada Handphone Untuk Mendukung Pembelajaran Mata Kuliah Media Reagen Dengan Model Untuk Mendukung Pembelajaran Mata Kuliah Media Reagen Dengan Model Problem Based Learning Pendahuluan Perguruan tinggi adalah jenjang pe. Inkuiri, 6(3), 41-48. 